\title{
YOUTH EMPLOYMENT TRENDS AND PROSPECTS IN THE EUROPEAN UNION: A COMPARATIVE ANALYSIS
}

\author{
Asta Visockaitė \\ Audronė Urmanavičienè \\ Mykolas Romeris University, Lithuania
}

\begin{abstract}
Youth employment is of great importance and relevance nowadays. The article analyses the issues of youth employment among the Member states of the European Union. According to the statistics and research data provided by the World Bank and Eurostat the situation of youth employment among the European Union member states and all across the Globe is deteriorating. The article focuses on analysing the programmes and initiatives of the European Union competent institutions and Member states of the European Union which aim to decrease the rates of youth unemployment.

Aim of the study: to evaluate the programs and initiatives aiming to decrease youth unemployment which are currently being implemented by the Institutions and Member states of the European Union.

Methods of the study: secondary analysis of the collected data (general overview).

Results: programs and measures aiming to decrease the youth unemployment rates in the EU Member states are being vastly initiated and implemented since early 2010. With the endorsement of the Plan to tackle and reduce youth unemployment rates, which foresees to accelerate the implementation of the Youth Employment and the Youth Guarantee initiatives, various youth employment promotional tools are being applied among the Member states. After analyzing and evaluating the aforementioned programs and initiatives carried out by the Institutions and Member states of the European Union, general tendencies of decreasing the youth unemployment rates may be determined.
\end{abstract}

Keywords: youth, employment, unemployment, European Union.

\section{Introduction}

Youth unemployment is a crucial and relevant issue to tackle not only among the Member states of the European Union but in a Global scope as well, so employment issues are considered to be a priority.

Employment is understood as legitimate (i.e. not prohibited by law) actions of labour carried out by persons, resulting in tangibles or services in order to satisfy the needs of individuals and the community and to provide income (Vainiene R., 2008). A person is also to be considered employed in the aforementioned sense in those cases when one is unemployed temporarily, e.g. is on vacation or ill, yet the person still maintains the working ties with a concrete working position in a company, establishment, institution or (one's own) business.

The issue of unemployment remains object to both political and economical debate. Economists analyse unemployment seeking to determine the 
reasons of it, its levels, macro and micro economical loss of unemployment, where the politicians aim to prepare and improve the employment policy of the Governments.

Both Lithuanian and foreign academics and scholars consider the issue of employment to be one of the main and crucial socio-economical problems: B.Martinkus (2005), D.Beržinskienė (2005), P.Havlik, (2007), M.Boianovsky (2003). There is a significant number of researches, articles and studies carried out regarding employment yet there is a lack of research of youth employment and the aforementioned issue is mostly analysed by economists: R.B.Freeman (1982, 2000), J.Medoff (1982), D.G.Blanchflower (2000), N.O'Higgins (2001).

Lithuanian scholars who examine and analyse the issue of youth employment are L.Okunevičiūtè Neverauskienè (2007, 2008, 2012), B.Gruževskis, (2007) J.Moskvina (2008), A.Pocius (2007), V.Česnuitytė (2008, 2012) and others.

Youth commonly is described similarly in countries as being a group of persons aged 14-15 to 29-30. The Fundaments of Youth Act of the Republic of Lithuania defines youth as persons aged 14-29 (Lietuvos Respublikos Jaunimo politikos pagrindų įstatymas Nr. IX-1871, $2003 \mathrm{~m}$. gruodžio $4 \mathrm{~d}$ ).

According to the data provided by the Lithuanian department of statistics there were 631000 persons aged 14-29 living in Lithuania in 2013, making 21 percent of the whole population of Lithuania in 2013 (Information provided by the Lithuanian department of statistics. www.stat.gov.lt). During the last decade the number of persons aged 14-29 living in Lithuania has reduced by 145000 which makes up 18,7 percent (http://osp.stat.gov.lt/documents/10180/259432/ Lietuvos_jaunimo_statistinis_portretas.pdf).

The objective of the article is to determine the tendencies and perspectives of youth employment by providing a thorough analysis of the programmes and initiatives conducted by the institutions of the European union and the Governments of the Member states of the European union which aim to reduce the youth unemployment rates.

\section{Tasks to fulfil in order to attain the objective:}

1. To analyse the programs and initiatives conducted by the EU institutions and the governmental authorities of EU Member states which particularly aim to reduce youth unemployment rates.

2. To compare the levels general unemployment and youth unemployment in distinct EU Member states.

Methods of the research:

Analysis of data gathered by research and analysis of statistical material. 


\section{Programs conducted by the $\mathrm{EU}$ institutions and Member states to reduce the rates of youth unemployment}

In 2010 the European Union initiated a significant number of programs aiming to reduce youth unemployment. Youth on the Move is an initiative to improve the conditions of youth education and possibilities of employment by encouraging the youth to participate in various scholarship programs and to participate or study in educational programs. This was expected to be achieved by encouraging EU Member states to ease the transition period and procedure going from schools and other education facilities directly to working places by adjusting and altering the youth education and training programs so that they would be more in compliance with the actual needs of youth (http://ec.europa.eu/social/main.jsp?catId=950\&langId=en).

As a part of Youth on the Move in 2012 another program called Your first EURES Job was initiated - a mobility program aiming to assist young European citizen to get employed in EU. EU citizens aged 18-30 which were legally living in a Member state were able to participate. (http://ec.europa.eu/social/main.jsp? catId $=993$ \&langId $=$ en).

Another important element was the Youth opportunities initiative implemented in the academic year of 2012-2013. This program was intended to help persons which do not have a secondary education by encouraging them to either go back to finish their studies or to engage in vocational schools to obtain a qualification of great request in the employment market. The objective of the initiative was to increase the possibilities to get employed in another EU Member state by promoting a close cooperation with political institutions, business and the unions on a regional and local level (http://ec.europa.eu/social/ main.jsp? catId $=1006 \&$ lang $I d=$ en).

In 2012 by the initiative of the European Commission Youth employment working groups were established in Greece, Ireland, Italy, Latvia, Lithuania, Portugal, Slovakia and Spain. Groups of representatives from the Member state and the European Commission aimed to promote the establishment of new workplaces specifically for young people and to facilitate the access to funding for the small and medium businesses (http://europa.eu/rapid/press-release_ MEMO-13-464_en.htm).

Based on a request made by the European Parliament and the European Council in 2012 the European Commission presented a package of measures to reduce the rates of youth unemployment. The objective of the Youth employment package was to create conditions for people younger than 25 years to get a high quality work proposal in a period of 4 months after the person's dismissal or after the person has graduated from school. Moreover the project seeked to create better conditions for continuous learning, apprenticeships or traineeships. With this package there was also an intent to create the European Apprenticeship Alliance in order to increase the quality of the apprenticeships 
and the scope of the education provided (http:/ec.europa.eu/social/main.jsp? langId $=$ en\&catId $=1036 \&$ newsId $=1731 \&$ furtherNews $=$ yes).

In addition the Youth guarantee initiative was intended to facilitate the implementation of the "Europa 2020" strategy which foresees three key goals: to make at least 75 percent of people aged 20-64 employed; to reduce the number of persons without a secondary education to less than 10 percent; to create possibilities for at least 20 million people to ford out of poverty and social exclusion. The European Council agreed upon the Youth guarantee initiative in April, 2013. The aforementioned initiative's objective was to ensure that any person younger than 25 years would receive a high quality job offer in four months or he would be offered an opportunity to pursue a continuing education, apprenticeship or traineeship. The Youth guarantee initiative presented six main measures: fostering cooperation between business representatives, educational facilities, employment agencies and state institutions; promoting early intervention and activity encouragement; integration of persons into the job market; the effective usage of financial aid provided by the EU structural funds; evaluation of the system; constant improvement and immediate implementation. In addition providing the youth with relevant information, fostering entrepreneurship among students, encouraging them to continue their studies or to enrol in apprenticeships was also emphasised. The initiative invited youth organizations to take part in the process as they may find an easier approach to young people than the representatives of the private or public sectors. EU Member states were urged to introduce taxation reductions for enterprises which employ young people, additionally providing the employers with targeted and well-planned salary subsidies in order to embolden the employers to create more opportunities for young people to get employed or enrol in apprenticeships or traineeships. The importance of promoting youth to initiate their own businesses is also noted in the program. The initiative also urged the governmental authorities to recognize non-formal education equally as formal and to exchange positive experiences and practise with the participants (http:/eurlex.europa.eu/LexUriServ/LexUriServ.do?uri=SWD:2012:0409:FIN:EN:PDF).

Various sources acknowledge the models used in Sweden and Finland as models to be followed while implementing the Youth guarantee initiative (http://www.eurofound.europa.eu/publications/htmlfiles/ef1242.htm). The northern European countries approached the youth employment issue much earlier than other EU Member states. The first actual Youth guarantee initiative was first carried out in Sweden in 1984, Norway took action in 1993, Finland and Denmark implemented the projects in 1996. Even though during the first attempts to implement the project several problems were experienced, especially in the 90s, the problems did not prevent the initiatives from taking force, on the contrary - the projects were constantly being renewed.For example in 2007 a renewed Youth guarantee initiative (En jobbgaranti for ungdommar) took place in Sweden, improved versions of the initiative (Nuorten Yhteiskuntatakkuu) 
were presented in Finland in 2005, 2010 and 2013. Public employment facilities played the key role and the programs were based on the actual needs of the young unemployed persons and accordingly the persons were offered either a workplace or an opportunity for studies or professional training.

The European Council agreed upon the initiative by adopting a Youth guarantee recommendation in addition stating that the Member states must endeavour to provide balance between the demand and supply in the labour market. The countries were urged to embolden the persons to improve their skills in information and communication technologies and that the certificates granted during and after the studies and/or training would be recognized equally on an international level. The aforementioned recommendation requested the states to provide more opportunities and better conditions for the youth to start their own businesses and to provide the society with information regarding individual and independent employment. A significant emphasis has been put on the necessity to integrate unemployed young persons and persons with an educational gap or who are currently not engaged in educational programs. It was noted that there is a ponderable lack of specialist in the fields of information and communication technologies, "green" economics, health and social care.

Another relevant projects is the European Alliance for Apprenticeships initiated on 17 February, 2013. The key objectives were to tackle the issue of youth unemployment by improving the conditions, accessibility and quantities of apprenticeships and by altering the attitude of young people towards apprenticeships. It is fair to state that apprenticeships and education based on actual labour activities makes the transition from the educational environment to the labour market much simpler. This strategy involves private businesses in solving the youth unemployment issues because the business sector has a wide access to various databases of traineeship candidates and they are able to provide the sector with a highly qualified labour force (http://ec.europa.eu/ social/main.jsp?langId=lt\&catId=89\&newsId=1934\& furtherNews=yes).

In the meeting of the leaders of the European Council which took place 2728 June, 2013 another program of measures to cope with youth unemployment was agreed on. The plan was supposed to accelerate the implementation of the Youth employment initiative and the Youth guarantee initiative.

In 19 June, 2013 the European Commission adopted a communication named Working together for Europe's young people: a call to action on youth unemployment which analysed the measures which were used to solve the youth unemployment issue at the time and the actions necessary to be taken into force immediately in order to return the young persons back to being employed or back to education facilities.

These factors were excluded and emphasised in the communication:

- The implementation and actual realization of the Youth guarantee initiative;

- Investing into young people via the European structural funds; 
- Active financing of the primary stage of the Youth employment initiative;

- Simplifying and making the transition from education facilities to employment easier and more possible by providing a high supply of high quality traineeships and apprenticeships and lowering the lack of skills of young people;

- To hasten the reformation process to a introduce the real EU labour market;

- Measures to assist the creation of new workplaces and promoting youth employment, especially the activities of small and medium enterprises.

The communication required the Member states which have a bigger that 25 percent youth unemployment rate to prepare an unequivocal plan on the implementation of the Youth guarantees initiative before October, 2013 showing how the institutions of the Member state plan to tackle the youth unemployment issue, what type of financing will be used, how will the progress be evaluated etc. Other countries with a lower youth unemployment rate were required to prepare their plans before March, 2014. The European Commission also encouraged to renew the Youth employment working groups project which would take place in those areas which have the biggest youth unemployment rates. Member states were asked to promote the movement of labour force in the European union, to strengthen the capacity of employment agencies and to support the small and medium enterprises which particularly employ persons younger than 25 years or offer them more apprenticeships comparing to bigger enterprises. The aforementioned communication recommended to appoint specific pay-outs or to reduce the social security pay-outs for employees with a lower qualification thus promoting the employers to hire more young people, to ensuring closer cooperation between the employment agencies and to modernize them, moreover a significant improvement would be to introduce entrepreneurship studies in high schools, vocational schools and universities. Additionally the communicate noted that it is important that the young persons would have well-developed multiple language, information technologies skills and would generally have more versatile skills. The European Commission prognoses that EU will have a shortage of personnel in the field of information and communication technologies by 900000 specialists in 2015. It also stated that certain education must be applied where the persons would be specifically trained to work in areas of health and social security and green economics hence the educational institutions were invited to adapt and adjust accordingly to the vastly changing tendencies of the market thus waiving educational programmes with less potential or demand in the market.

Having in mind that there is a constantly growing demand of employees with a high qualification the persons with no skills or low qualifications will 
encounter problems getting employed (http:/ec.europa.eu/europe 2020/ pdf/youth_lt.pdf).

\section{The levels of general unemployment and youth unemployment in the $\mathbf{E}$ Member states}

The International Labour Organization states that there are 75 million people (6 percent) aged 15-24 which are currently unemployed in the World. The latter number may be even bigger due to a certain amount of people which are not even participating in the labour market thus not included in the data and according to the World Bank there may be 260 million of these persons. According to a research carried out by The Economist there may be approximately 290 million young people in the World which do not participate in the labour market in any way (this number is an equivalent of the number of people living in all of the states of USA, or constitutes one fourth of the total amount of young people globally). However almost one fourth of the so-called passive youth is women in South Asia which do not engage in employment relations due to strict traditions. On the other hand one third of the young people from well-developed countries work under fixed-term contracts whereas one fifth of the youth living in the less-developed countries work either unofficially, without pay or in their families (The Economist. Youth unemployment: generation jobless. http://www.economist.com/news/international/21576657around-world-almost-300m-15-24-year-olds-are-not-working-what-has-caused).

The youth unemployment level in March, 2013 was 23,5 percent, the rate of unemployed persons aged 15-24 was twice the rate of general unemployment (9,3 percent). Approximately 6 million of young persons were unemployed, an estimated 7,5 million of all young people were not enrolled in educational programs. This concluded 12,9 percent of all young European citizens. One out of five EU citizens did not manage to find a job, and even if a person was employed, mostly they were working under a fixed-term agreement or was engaged in a season occupation. At the same time there were 2 million vacant workplaces. Over the past four years the number of youth employment level dropped three times faster than levels of any other age groups.

One of the main reasons of this vast growth of youth unemployment was the financial crisis which caused a lot of cut-offs in enterprises mainly minimizing the number of working places thus dismissing young employees and even if young persons were to be employed, there was a strict experience requirement. Despite the effort to reduce youth unemployment the general situation regarding the issue got worse by the year and the poor youth employment situation still remains to this day. In some of the EU Member states the general level of unemployment rose three times. In 2013 3,4 million less young people were employed comparing to the number in 2007. More than 30,1 percent of the unemployed persons younger than 25 years were unemployed for 
more than 12 months in a row. It was estimated that the general expenses of EU Member states due to youth unemployment made up 1,2 percent of the GDP.

Table 1. General unemployment rate and youth unemployment rate in EU Member states

\begin{tabular}{|c|c|c|c|c|c|c|c|}
\hline Country & $\begin{array}{l}\text { Unemploy } \\
\text { ment rate } \\
2009 \text { m., } \\
\%\end{array}$ & $\begin{array}{c}\text { Youth } \\
\text { unem- } \\
\text { ployment } \\
\text { rate } 2009 \\
\text { m., } \%\end{array}$ & $\begin{array}{c}\text { Unem- } \\
\text { ployment } \\
\text { rate } 2012 \\
\text { m., } \%\end{array}$ & $\begin{array}{c}\text { Youth } \\
\text { unem- } \\
\text { ployment } \\
\text { rate } 2012 \\
\text { m., \% }\end{array}$ & $\begin{array}{l}\text { The gap } \\
\text { between } \\
\text { unem- } \\
\text { ployment } \\
\text { and youth } \\
\text { unemploy } \\
\text { ment rates } \\
2009 \text { m., } \\
\text { percentage } \\
\text { points }\end{array}$ & $\begin{array}{l}\text { The gap } \\
\text { between } \\
\text { unem- } \\
\text { ployment } \\
\text { and youth } \\
\text { unem- } \\
\text { ployment } \\
\text { rates } \\
2012 \mathrm{~m} . \text {, } \\
\text { percentage } \\
\text { points }\end{array}$ & $\begin{array}{l}\text { The gap } \\
\text { change } \\
\text { between } \\
\text { youth } \\
\text { unem- } \\
\text { ployment } \\
\text { and unem- } \\
\text { ployment } \\
\text { in } 2012 \text {, } \\
2009, \\
\text { percentage } \\
\text { points }\end{array}$ \\
\hline Austria & $4,8 \%$ & $10,0 \%$ & $4,3 \%$ & $8,7 \%$ & $5,2 \%$ & $4,4 \%$ & $-0,8 \%$ \\
\hline Denmark & $6,0 \%$ & $11,8 \%$ & $7,5 \%$ & $14,1 \%$ & $5,8 \%$ & $6,6 \%$ & $0,8 \%$ \\
\hline Estonia & $13,8 \%$ & $27,5 \%$ & $10,2 \%$ & $20,9 \%$ & $13,7 \%$ & $10,7 \%$ & $-3,0 \%$ \\
\hline Greece & $9,5 \%$ & $25,8 \%$ & $24,3 \%$ & $55,3 \%$ & $16,3 \%$ & $31,0 \%$ & $14,7 \%$ \\
\hline Spain & $18,0 \%$ & $37,8 \%$ & $25,0 \%$ & $53,2 \%$ & $19,8 \%$ & $28,2 \%$ & $8,4 \%$ \\
\hline Italy & $7,8 \%$ & $25,4 \%$ & $10,7 \%$ & $35,3 \%$ & $17,6 \%$ & $24,6 \%$ & $7,0 \%$ \\
\hline Latvia & $18,2 \%$ & $36,2 \%$ & $14,9 \%$ & $28,4 \%$ & $18,0 \%$ & $13,5 \%$ & $-4,5 \%$ \\
\hline Lithuania & $13,6 \%$ & $29,0 \%$ & $13,3 \%$ & $26,4 \%$ & $15,4 \%$ & $13,1 \%$ & $-2,3 \%$ \\
\hline $\begin{array}{c}\text { The } \\
\text { Netherlands }\end{array}$ & $3,7 \%$ & $7,7 \%$ & $5,3 \%$ & $9,5 \%$ & $4,0 \%$ & $4,2 \%$ & $0,2 \%$ \\
\hline Portugal & $10,6 \%$ & $24,8 \%$ & $15,9 \%$ & $37,7 \%$ & $14,2 \%$ & $21,8 \%$ & $7,6 \%$ \\
\hline Germany & $7,8 \%$ & $11,2 \%$ & $5,5 \%$ & $8,1 \%$ & $3,4 \%$ & $2,6 \%$ & $-0,8 \%$ \\
\hline
\end{tabular}

Remark: Table 1 is prepared according to the information provided by Eurostat. http://epp.eurostat.ec.europa.eu/statistics_explained/index.php/Unemployment_statistics

In 2012 the highest level of youth unemployment was recorded in Greece (55,3 percent), Spain (53,2 percent) and Portugal (37,7 percent). The gap between the general unemployment and youth unemployment rates was the biggest in Greece, Spain, Portugal and Italy (21,8 - 31 percentage points). The lowest rate of youth unemployment among the EU Member states was recorded in Germany ( 8,1 percent), Austria ( 8,7 percent), The Netherlands $(9,5$ percent) and Denmark $(14,1$ percent). The gap between the general unemployment and youth unemployment rates were also the lowest in the aforementioned countries (2,6-6,6 percentage points).

Regarding the Baltic states, the highest rate of youth unemployment was recorded in Latvia (28,4 percent), the level of youth unemployment was a little lower in Lithuania (26,4 percent) and the lowest level was recorded in Estonia $(20,9$ percent). The gap between the general unemployment and youth unemployment rates in the Baltics was 10,7-13,5 percentage points. 
Comparing the youth unemployment rates in 2012 and 2009, the biggest reduction was seen in Latvia (by 7,8 percentage points), Estonia (by 6,6 percentage points), Germany (by 3,1 percentage points) and Lithuania (by 2,6 percentage points).

Analysing the changes of the gap between the general unemployment and youth unemployment rates of 2012 and 2009 it may be stated that the gap decreased the most in the Baltic states (in Latvia - by 4,5 percentage points, Estonia - by 3 percentage points, Lithuania - by 2,3 percentage points).

All in all it may be stated that despite the various measures, initiatives and programs implied during the years since 2010 in order to cope with the youth unemployment problem, they seize to show significant effectiveness since the youth unemployment issue still remains to be crucial and open for solving having in mind that the youth unemployment rates increased in most of the EU Member states and that the gap between the general unemployment and youth unemployment rates grew as well.

\section{Conclusion}

By approving the schemes of measures to cope with the youth unemployment which foresee speeding up the implementation of the Youth employment initiative and the Youth guarantee initiative, different measures are being implied in different EU Member states. It is evident that some countries are likely to apply structural and combined projects, which aim to aid particular groups of the youth - acquiring social and professional skills, promoting entrepreneurship etc. Yet in other countries another approach is taken by orientating the measures not to affect the young persons directly or to aid them financially but pursuing various advantages and exemptions for the employers themselves - reduction of social security pay-outs, compensation of salaries, granting subsidies for creating a workplace etc.

Despite the vast concern about the youth unemployment issue, the initiatives and measures being applied at the EU level since 2010, the general level of unemployment and especially the youth unemployment rates among all of the EU Member states (as globally as well) are increasing thus fundamental and substantive structural changes are essential.

\section{References}

Blanchflower, D. G., Freeman, R B. (2000). Youth Employment and Joblessness in Advanced Countries. Chicago: University of Chicago Press.

Boianovsky, M. Some Cambridge reactions to The General Theory: David Champernowne and Joan Robinson on full employment http://cje.oxfordjournals. org/cgi/content/abstract/29/1/73 [acessed 20150212 ].

Česnuitytė, V., Okunevičiūtė Neverauskienè, L. (2012). Socialinè politika: integracija ị darbo rinka: vadovèlis. Vilnius: Eugrimas. 
European Commission. Employment, Social Affairs \& Inclusion. Launch of European Alliance for Apprenticeships. [interactive]. [acessed 2015-02-12]. Available from Internet:

http://ec.europa.eu/social/main.jsp?langId=1t\&catId=89\&newsId=1934\&furtherNews=y es.

European Commission. Employment, Social Affairs \& Inclusion. Your first EURES Job. [interactive]. [acessed 2015-02-10]. Available from Internet: http://ec.europa.eu/ social $/$ main.jsp? catId=993\&langId=en.

European Commission. Employment, Social Affairs \& Inclusion. Youth on the Move. [interactive]. [acessed 2015-02-09]. Available from Internet: http://ec.europa.eu/ social $/$ main.jsp?catId $=950 \&$ langId $=$ en .

European Commission. Employment, Social Affairs \& Inclusion. Youth Opportunities Initiative. [interactive]. [acessed 2015-02-10]. Available from Internet: http://ec.europa.eu/social/main.jsp?catId=1006\&langId=en.

European Commission. Employment, Social Affairs \& Inclusion. Youth employment: Commission proposes package of measures. [interactive]. [acessed 2015-02-06]. Available from Internet: http://ec.europa.eu/social/main.jsp?langId=en\&catId $=1036 \&$ newsId $=1731$ \& furtherNews $=$ yes.

European Commission. EU measures to tackle youth unemployment. [interactive]. [acessed 2015-02-08]. Available from Internet: http://europa.eu/rapid/press-release_MEMO-13464 en.htm.

European Commission. Proposal for a Council Recommendation on Establishing a Youth Guarantee. [acessed 2015-02-01]. Available from Internet: http://eur-lex.europa.eu/ LexUriServ/LexUriServ.do? uri=SWD:2012:0409:FIN:EN:PDF.

European Monitoring Centre on Change. Youth Guarantee: Experiences from Finland and Sweden. [acessed 2015-02-01]. Available from Internet: http://www.eurofound.europa.eu/publications/htmlfiles/ef1242.htm.

Europos Komisija. Komisijos komunikatas dèl raginimo spręsti Europos jaunimo nedarbo problema. Briuselis, 20130619 COM(2013) 447 final. [acessed 2015-02-10]. Available from Internet: http://ec.europa.eu/europe2020/pdf/youth_lt.pdf.

Eurostat Statistic. [interactive]. [acessed 2015-02-10]. Available from Internet: http://epp.eurostat.ec.europa.eu/portal/page/portal/statistics/search_database.

Freeman, R. B., Medoff, J. L. (1982). Why does the Rate of Youth Labor Force Activity Differ across Surveys? In The Youth Labor Market Problem: its Nature, Causes, and Consequences. London, Chicago: Universty of Chicago Press.

Gruževskis, B., Okunevičiūtė Neverauskienè, L., Česnuitytė, V. (2007). Asmenų, neturinčių pagrindinio išsilavinimo, integracijos i Lietuvos darbo rinką problemos. Socialinis darbas: mokslo darbai. Vilnius: MRU. Nr. 6(2).

Havlik, P. (2007). Structural change, produktivity and employment in the new EU Member States. Economic Restructuring and Labour Markets in the Accession Countries http://ec.europa.eu/employment_social/employment_analysis/restruct/struct_change_ca se_en.pdf [acessed 201502 12].

Lietuvos jaunimo statistinis portretas. http://osp.stat.gov.lt/documents/10180/259432/ Lietuvos_jaunimo_statistinis_portretas.pdf [accessed 2015-02-15].

Lietuvos Respublikos Jaunimo politikos pagrindu istatymas Nr. IX-1871, $2003 \mathrm{~m}$. gruodžio 4 d. (The Fundaments of Youth Act of the Republic of Lithuania No. IX-1871, 4 December, 2003.) [interactive]. [acessed 2015-02-07]. https://www.e-tar.lt/portal/ 1t/legalAct/TAR.92E111F705DD.

Martinkus B., Beržinskienè D. (2005). Lietuvos gyventojų užimtumo ekonominiai aspektai. Kaunas: Technologija. 
O'Higgins, N. (2001). "The Characteristics of Youth Unemployment”, Youth Unemployment and Employment Policy: a Global Perspective. Geneva: International Labour Office.

Okunevičiūtė Neverauskienė, L., Gruževskis, B., Pocius, A., Moskvina, J. (2007). Jaunimo isitvirtinimo Lietuvos darbo rinkoje galimybiu tobulinimas (studija). Vilnius: Darbo ir socialinių tyrimų institutas.

Okunevičiūtė Neverauskienė, L., Moskvina, J. (2008). Socialiai pažeidžiamo jaunimo problemos integracijos i darbo rinką kontekste. Filosofija. Sociologija. Vilnius: Lietuvos Mokslų Akademijos leidykla. T. 19, nr. 2

The data of Lithuanian Department of Statistics. [interactive]. [accessed 2015-02-07]. www.stat.gov.lt.

The Economist. Youth unemployment: generation jobless. [accessed 2015-02-12]. Available from Internet: http://www.economist.com/news/international/21576657-around-worldalmost-300m-15-24-year-olds-are-not-working-what-has-caused.

Vainienè, R. (2008). Ekonomikos terminu žodynas. Vilnius: Tyto alba. 